\title{
Radiotherapy in patients with connective tissue diseases
}

The decision to offer radiotherapy in patients with connective tissue diseases continues to be challenging. Radiotherapy might trigger the onset of connective tissue diseases by increasing the expression of self-antigens, diminishing regulatory T-cell activity, and activating effectors of innate immunity (dendritic cells) through Toll-like receptor-dependent mechanisms, all of which could potentially lead to breaks of immune tolerance. This potentia risk has raised some debate among radiation oncologists about whether patients with connective tissue diseases can tolerate radiation as well as people without connective tissue diseases. Because the number of patients with cancer and connective tissue diseases needing radiotherapy will probably increase due to improvements in medical treatment and longer life expectancy, the issue of interactions between radiotherapy and connective tissue diseases needs to be clearer. In this Review, we discuss available data and evidence for patients with connective tissue diseases treated with radiotherapy.

\section{Introduction}

Connective tissue diseases are a heterogeneous group of autoimmune rheumatic diseases characterised by immune system dysregulation and the development of autoantibodies. Patients typically alternate between active or symptomatic periods and non-active or quiescent phases. Connective tissue diseases have historically been considered an absolute or relative contraindication to radiotherapy because of the hypothesis of a greater risk of severe radiotherapyrelated acute and late complications.

Few reports have been made of the outcomes of patients with newly diagnosed connective tissue diseases (or exacerbation of pre-existing disease) who need radiotherapy (table 1,2$).^{1-21}$ Although an analysis of the little available data shows that risk of radiotherapy toxicity in patients with connective tissue diseases seems to be based largely on anecdotal evidence, radiation oncologists remain hesitant. In 1998, the American College of Radiology ${ }^{22}$ concluded that, "a history of collagen vascular disease is a relative contraindication to breast conservation treatment because published reports indicate that such patients tolerate irradiation poorly. Most radiation oncologists will not treat patients with scleroderma or active systemic lupus erythematosus, considering either an absolute contraindication." Thus, radiotherapy has been underused in patients with connective tissue diseases who have cancer. ${ }^{16}$

With improved medical treatments, prognosis for patients with connective tissue diseases has improved. The 5-year survival in systemic lupus erythematosus has increased from about $40 \%$ in the 1950 s, to $90 \%$ in the $1980 \mathrm{~s}$, to more than $90-95 \%$ nowadays. ${ }^{23}$ Therefore, a higher number of patients with connective tissue diseases are expected to be diagnosed with cancer and will potentially be eligible for oncological treatment, including radiotherapy. Substantial improvements have been made in radiation technology, including the development of intensity-modulated radiotherapy and image-guided radiotherapy. These techniques are available in clinical practice, potentially minimising acute and late local side-effects. Thus, new radiotherapy techniques could be considered feasible even in patients Review, we analyse evidence and discuss the available data for radiotherapy in patients with connective tissue diseases.

Connective tissue diseases, cancer environments, and radiation interactions

Connective tissue diseases are chronic and debilitating autoimmune disorders that cause substantial morbidity and mortality and disproportionately affect women. These diseases include rheumatoid arthritis, systemic sclerosis, scleroderma, systemic lupus erythematosus, dermatomyositis, and vasculitis. Connective tissue diseases often develop after environmental triggering via cellular pathways in genetically susceptible individuals with disease-associated polymorphisms. ${ }^{24}$ However, the specific cellular and molecular mechanisms leading to connective tissue diseases, and factors that establish involved organs are involved, are poorly understood.

Associations between connective tissue diseases and cancer are being increasingly investigated. Links between them are multifaceted and have different relationships in terms of frequency, timing, and type of cancers. Several studies have highlighted the dynamic and bidirectional interactions occurring at the cancer-immune system interface that might be relevant to the origins of autoimmunity. ${ }^{25}$ Data for patients with systemic sclerosis and concomitant cancer suggest that, in some cases, autoimmunity might be triggered by an autoantigen mutation in the patient's cancer. ${ }^{26,27}$ Also, connective tissue diseases might cause changes in immune function that could be affected by immunosuppressive therapy. ${ }^{24}$ Although the evidence was not overwhelming, some investigators have reported that these changes in immune function did affect radiotherapy toxicity. ${ }^{28}$ This bidirectional hypothesis was based on the idea that some connective tissue diseases share a common pathological pathway of vascular obliteration and fibrosis due to heightened inflammation and a clinical pattern of possible systemic involvement. The potential for radiotherapy to augment these pathological changes became a topic of investigation. with connective tissue diseases who have cancer. In this
Lancet Oncol 2016; 17: e109-17 Radiation Oncology Department, Sacro Cuore Hospital, Negrar-Verona, Italy (N Giaj-Levra MD,

A Fiorentino MD, S Fersino MD R Mazzola MD, F Ricchetti MD, F Alongi MD); and Center of Research of Immunopathology and Rare Diseases-Coordinating Center of Piemonte and Valle d'Aosta Network for Rare Diseases, Department of Clinical and Biological Sciences, University of Torino, Italy, Turin, Italy (S Sciascia PhD, Prof D Roccatello MD)

Correspondence to: Dr Niccolò Giaj-Levra, Radiation Oncology Department, Sacro Cuore Hospital, Negrar-Verona 37024, Italy niccolo.giajlevra@sacrocuore.it 


\begin{tabular}{|c|c|c|c|c|c|c|c|}
\hline & Tumour type & $\begin{array}{l}\text { Patients with } \\
\text { connective tissue } \\
\text { disease }(n)\end{array}$ & $\begin{array}{l}\text { Type of connective } \\
\text { tissue disease }\end{array}$ & $\begin{array}{l}\text { Increase in } \\
\text { severe acute } \\
\text { toxicity }\end{array}$ & $\begin{array}{l}\text { Increase in } \\
\text { severe late } \\
\text { toxicity }\end{array}$ & Treatment & Conclusion \\
\hline Teo et al, $1989^{1}$ & Head and neck & 10 & Dermatomyositis & Yes & Yes & External-beam radiotherapy & Effect \\
\hline Fleck et al, $1989^{2}$ & Breast & 9 & Mixed & Yes & Yes & External-beam radiotherapy & Effect \\
\hline Varga et al, $1991^{3}$ & Mixed & 4 & $\begin{array}{l}\text { Progressive } \\
\text { systemic sclerosis }\end{array}$ & No & Yes & External-beam radiotherapy & Effect \\
\hline $\begin{array}{l}\text { Hareyama et al, } \\
1995^{4}\end{array}$ & Head and neck & 2 & Mixed & Yes & No & $\begin{array}{l}\text { Concurrent chemotherapy and } \\
\text { external-beam radiotherapy }\end{array}$ & Inconclusive* \\
\hline Bliss et al, $1996^{5}$ & Cervix & 5 & Mixed & Yes & No & $\begin{array}{l}\text { External-beam radiotherapy } \\
\text { and brachytherapy }\end{array}$ & Effect \\
\hline $\begin{array}{l}\text { Turesson et al, } \\
1996^{6}\end{array}$ & Breast & 35 & NA & NA & No & NA & No effect \\
\hline $\begin{array}{l}\text { Rakfal and Deutsch, } \\
1998^{7}\end{array}$ & Mixed & 6 & $\begin{array}{l}\text { Systemic lupus } \\
\text { erythematosus, } \\
\text { discoid lupus } \\
\text { erythematosus }\end{array}$ & No & No & External-beam radiotherapy & No effect \\
\hline Khoo et al, $2004^{8}$ & Anal cancer & 2 & $\begin{array}{l}\text { Systemic lupus } \\
\text { erythematosus }\end{array}$ & No & No & $\begin{array}{l}\text { Concurrent chemotherapy } \\
\text { and external-beam } \\
\text { radiotherapy }\end{array}$ & No effect \\
\hline Dragun et al, $2011^{9}$ & Breast & 9 & Mixed & No & No & $\begin{array}{l}\text { Intraoperative radiotherapy } \\
\text { and brachytherapy }\end{array}$ & No effect \\
\hline Lowell et al, $2011^{10}$ & Brain metastases & 14 & Mixed & No & No & Gamma knife & No effect \\
\hline
\end{tabular}

Radiotherapy acutely affects early responding tissues, such as the basal dermis and oral and gastric mucosa, by reducing proliferation. Radiation-induced obliteration of capillaries and small vessels is also well documented. ${ }^{28}$ In patients with connective tissue diseases, these acute effects might act in conjunction with immune-related damage caused by immune complex deposition, complement cascade activation, and infiltrating inflammatory cells (figure 1). Such common targeting might be additive to typical radiation-induced acute tissue injuries. ${ }^{11}$ The additive injury induced by both radiation and the pre-existing connective tissue diseases might also help to explain the potentially increased late effects noted in some of these patients after radiotherapy. ${ }^{3}$ Radiotherapy might trigger the onset of connective tissue diseases by enhancing the expression of self-antigens (eg, from apoptotic cell debris), diminishing regulatory T-cell activity, and activating effectors of innate immunity such as dendritic cells through Toll-like receptor-dependent mechanisms, all of which could potentially lead to a break of immune tolerance. ${ }^{25}$ This potential mechanism has raised a debate among radiation oncologists about whether patients with connective tissue diseases tolerate radiation as well as people with no connective tissue disease. ${ }^{29}$

Experimental evidence supports the hypothesis that the immune system is able to repress tumour cells and that immune surveillance has a key role in the identification and elimination of cancer cells. ${ }^{30}$ Three different phases have been described in the interaction between cancer cells and the immune system: elimination (which is still considered the cornerstone in the immune surveillance process), equilibrium between the immune system and cancer cells, and escape. ${ }^{30}$ Immune surveillance is considered a complex process involving different immune system cells-ie, CD8 cells, natural killer cells, CD4 cells, macrophages, and B lymphocytes. ${ }^{30}$ After radiotherapy, the disruption of the tissue architecture is associated with changes in blood flow (zones with hyperperfusion and hypoxia) and lymphatic function and an increase in interstitial pressure. ${ }^{31}$ Additionally, irradiation of the tumour and its microenvironment is associated with the proliferation of inflammatory signals detected by the immune system..$^{32}$ The resulting production of cytokines and chemokines then attracts antigen-presenting cells (dendritic cells) that, after uptake of tumour-associated antigens, cause CD8 activation involved in tumour killing (figure 1)..$^{33,34}$

Evidence is also increasing that inflammation contributes to cancer development and that cancer cells use inflammatory mechanisms to prevent immune-system activation and to protect the tumour from immune attack (equilibrium and escape phases). ${ }^{35}$ Moreover, inflammatory elements (such as chemokines and interleukins) released by tumour cells promote infiltration, progression of disease, and metastases (figure 2).$^{36}$

Various mechanisms might exist that exacerbate the pathophysiological response induced by radiation exposure in patients with connective tissue diseases. One potential mechanism includes the overexpression of profibrotic cytokines, such as transforming growth factor $\beta$ 


\begin{tabular}{|c|c|c|c|c|c|c|c|c|c|}
\hline & $\begin{array}{l}\text { Primary } \\
\text { tumour } \\
\text { site }\end{array}$ & $\begin{array}{l}\text { Patients with } \\
\text { connective tissue } \\
\text { disease (n) }\end{array}$ & $\begin{array}{l}\text { Type of connective tissue } \\
\text { disease ( } n)\end{array}$ & Study design & $\begin{array}{l}\text { Increase in } \\
\text { severe acute } \\
\text { toxicity }\end{array}$ & $\begin{array}{l}\text { Increase in } \\
\text { severe late } \\
\text { toxicity }\end{array}$ & $\begin{array}{l}\text { Median } \\
\text { radiotherapy dose }\end{array}$ & $\begin{array}{l}\text { Radiotherapy } \\
\text { technique }\end{array}$ & Conclusion \\
\hline $\begin{array}{l}\text { Ross et al, } \\
1993^{11}\end{array}$ & Mixed & 61 & $\begin{array}{l}\text { Rheumatoid arthritis } \\
\text { ( } n=39) \text {, systemic lupus } \\
\text { erythematosus }(n=13) \text {, } \\
\text { other }(n=9)\end{array}$ & $\begin{array}{l}\text { Matched pair } \\
\text { analysis }\end{array}$ & No & No & 56 Gy & $\begin{array}{l}\text { External-beam } \\
\text { radiotherapy, } \\
\text { brachytherapy }\end{array}$ & No effect \\
\hline $\begin{array}{l}\text { Morris et al, } \\
1997^{12}\end{array}$ & Mixed & 209 & $\begin{array}{l}\text { Rheumatoid arthritis } \\
\text { ( } n=131) \text {, systemic lupus } \\
\text { erythematosus }(n=25) \text {, } \\
\text { other }(n=53)\end{array}$ & Retrospective & No & Yes & $45 \mathrm{~Gy}$ & $\begin{array}{l}\text { External-beam } \\
\text { radiotherapy }\end{array}$ & Inconclusive* \\
\hline $\begin{array}{l}\text { Chen et al, } \\
2001^{13}\end{array}$ & Breast & 36 & $\begin{array}{l}\text { Rheumatoid arthritis } \\
\text { ( } n=17) \text {, systemic lupus } \\
\text { erythematosus }(n=5) \text {, } \\
\text { scleroderma }(n=4) \text {, other } \\
(n=10)\end{array}$ & $\begin{array}{l}\text { Matched pair } \\
\text { analysis }\end{array}$ & Yes & Yes & $64 \mathrm{~Gy}$ & $\begin{array}{l}\text { External-beam } \\
\text { radiotherapy, } \\
\text { brachytherapy }\end{array}$ & $\begin{array}{l}\text { No effect (effect in } \\
\text { scleroderma) }\end{array}$ \\
\hline $\begin{array}{l}\text { Phan et al, } \\
2003^{14}\end{array}$ & Mixed & 38 & $\begin{array}{l}\text { Systemic lupus } \\
\text { erythematosus }(n=21) \text {, } \\
\text { scleroderma }(n=2) \text {, other } \\
(n=15)\end{array}$ & $\begin{array}{l}\text { Matched pair } \\
\text { analysis }\end{array}$ & No & No & $55 \cdot 17 \mathrm{~Gy}$ & $\begin{array}{l}\text { External-beam } \\
\text { radiotherapy, } \\
\text { brachytherapy }\end{array}$ & $\begin{array}{l}\text { No effect (effect in } \\
\text { scleroderma) }\end{array}$ \\
\hline $\begin{array}{l}\text { Livet al, } \\
2004^{15}\end{array}$ & Prostate & 15 & NA & Prospective & No & Yes & 66 Gy & $\begin{array}{l}\text { External-beam } \\
\text { radiotherapy }\end{array}$ & Effect \\
\hline $\begin{array}{l}\text { Benk et al, } \\
2005^{16}\end{array}$ & Mixed & 38 & $\begin{array}{l}\text { Systemic lupus } \\
\text { erythematosus ( } \mathrm{n}=38 \\
4 \text { radiotherapy treated) }\end{array}$ & Retrospective & No & No & NA & NA & No effect \\
\hline $\begin{array}{l}\text { Gold et al, } \\
2007^{17}\end{array}$ & Mixed & 20 & Scleroderma $(n=20)$ & Retrospective & No & No & 36 Gy & $\begin{array}{l}\text { External-beam } \\
\text { radiotherapy, } \\
\text { brachytherapy }\end{array}$ & No effect \\
\hline $\begin{array}{l}\text { Lin et al, } \\
2008^{18}\end{array}$ & Mixed & 73 & $\begin{array}{l}\text { Rheumatoid arthritis } \\
\text { ( } n=33) \text {, systemic lupus } \\
\text { erythematosus }(n=13) \text {, } \\
\text { scleroderma }(n=9) \text {, other } \\
(n=18)\end{array}$ & Retrospective & No & Yes & NA & $\begin{array}{l}\text { External-beam } \\
\text { radiotherapy }\end{array}$ & $\begin{array}{l}\text { No effect (effect } \\
\text { unknown in pelvic site } \\
\text { systemic lupus } \\
\text { erythematosus or } \\
\text { scleroderma) }\end{array}$ \\
\hline $\begin{array}{l}\text { Gold et al, } \\
2008^{19}\end{array}$ & Mixed & 41 & $\begin{array}{l}\text { Progressive systemic } \\
\text { sclerosis }(n=20) \text {, systemic } \\
\text { lupus erythematosus } \\
(n=21)\end{array}$ & Retrospective & NA & No & NA & $\begin{array}{l}\text { External-beam } \\
\text { radiotherapy, } \\
\text { brachytherapy }\end{array}$ & Inconclusive* \\
\hline $\begin{array}{l}\text { Pinn et al, } \\
2008^{20}\end{array}$ & Mixed & 21 & $\begin{array}{l}\text { Systemic lupus } \\
\text { erythematosus ( } n=21)\end{array}$ & Retrospective & Yes & No & 49.75 Gy & $\begin{array}{l}\text { External-beam } \\
\text { radiotherapy, } \\
\text { brachytherapy, } \\
\text { intensity-modulated } \\
\text { radiotherapy }\end{array}$ & No effect \\
\hline $\begin{array}{l}\text { Patel et al, } \\
2012^{21}\end{array}$ & Mixed & 12 & $\begin{array}{l}\text { Discoid lupus } \\
\text { erythematosis ( } n=12 \text { ) }\end{array}$ & Retrospective & No & No & 69 Gy & $\begin{array}{l}\text { External-beam } \\
\text { radiotherapy, } \\
\text { brachytherapy }\end{array}$ & No effect \\
\hline
\end{tabular}

(TGF $\beta$ ) and interleukin 1. Radiation injury in healthy tissues is usually characterised by the appearance of a fibrinous exudate within the stroma and by deposition of extracellular matrix components, including collagen, through myofibroblasts produced by fibroblast activation and differentiation. ${ }^{37}$ In some connective tissue diseases (such as systemic sclerosis) in which TGF $\beta$ concentrations are already increased, late effects after radiotherapy might be more evident. ${ }^{3}$ Another potential mechanism involves radiation microvascular damage in a context of vasculitis, leading to increased late effects and reduced tolerance to treatment. After radiation, endothelial cell injury and tissue hypoxia stimulate the recruitment into the tissue of inflammatory circulating cells, such as macrophages, which are a source of profibrotic mediators, including TGF $\beta 1.38,39$ Additionally, increased concentrations of proangiogenesis factors (eg, VEGF) as a result of vascular damage and leakage of vessels in response to radiotherapy could exacerbate late effects such as dermal atrophy, telangectasia, necrosis, and fibrosis. ${ }^{40}$ Finally, radiationinduced damage to basement membranes causes this to become a target tissue, leading to increased autoimmunity. ${ }^{12,28}$

\section{Preclinical studies and case reports}

Some studies have used in-vitro sensitivity to radiation in lymphocytes from patients with connective tissue diseases to assess risk indicators for radiation-related 


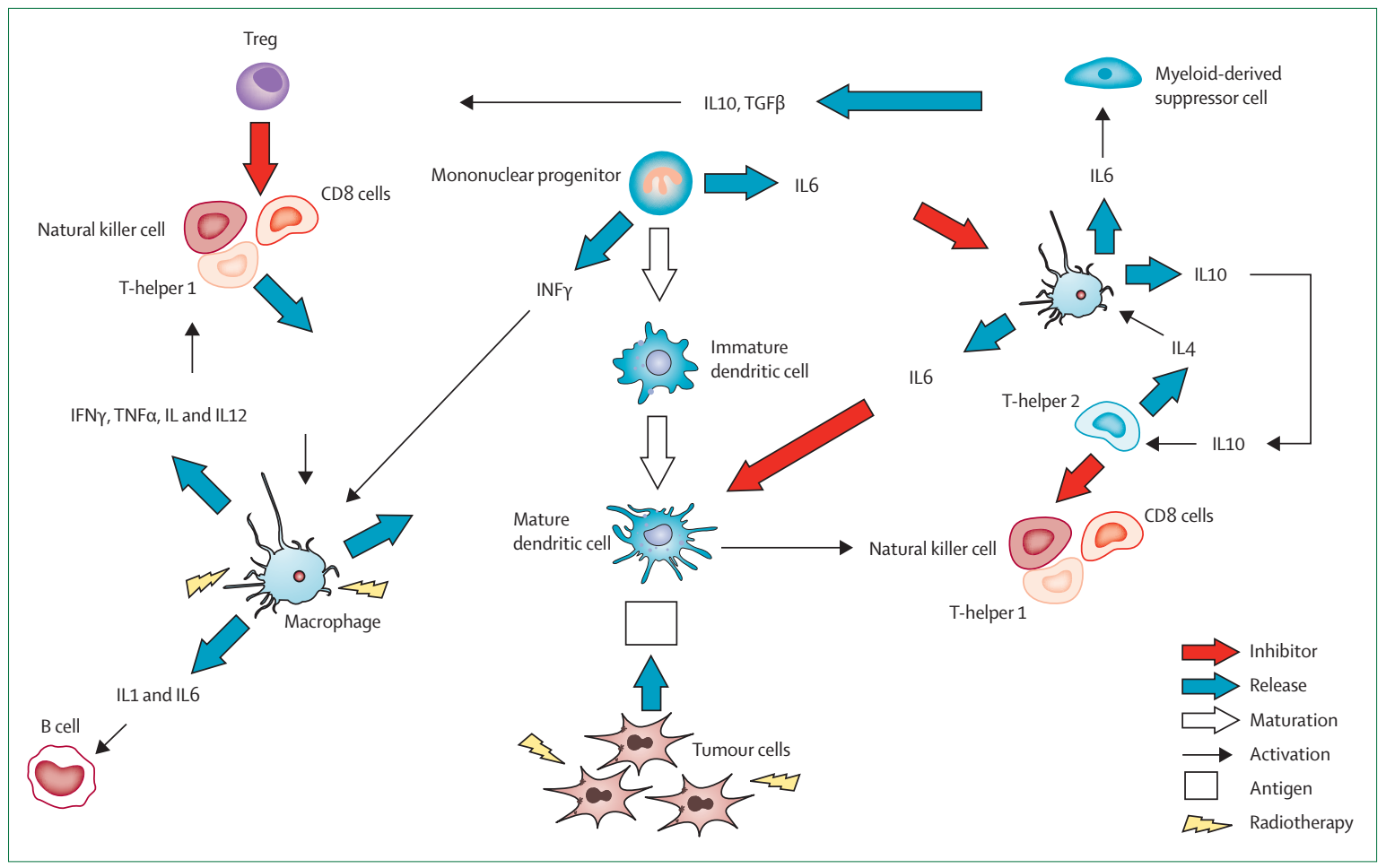

Figure 1: Main immune cells, interleukins, and cytokines involved in immune surveillance TGF=transforming growth factor. IFN=interferon. IL=interleukin. TNF=tumour necrosis factor.

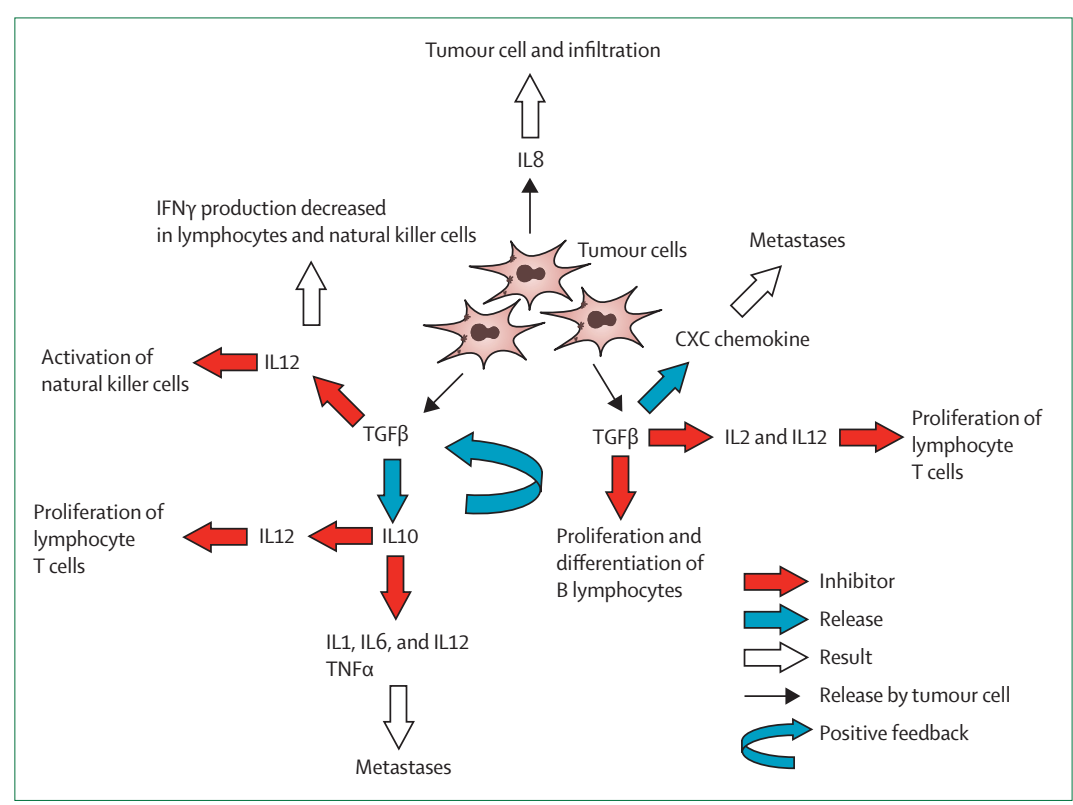

Figure 2: Tumour-cell mechanisms against the immune system

TGF=transforming growth factor. $C X C=C X C$ chemokine. IFN=interferon. IL=interleukin. TNF=tumour necrosis factor.

side-effects. ${ }^{41-43}$ Carrillo-Alascio and colleagues ${ }^{41}$ used pulsed-field gel electrophoresis to quantify the initial radiation-induced DNA double-strand breaks in peripheral lymphocytes from 52 patients with systemic lupus erythematosus. Systemic lupus erythematosus did not confer a higher intrinsic risk of radiosensitivity when compared with 48 healthy participants without connective tissue diseases. ${ }^{41}$ In another study, ${ }^{43}$ the same investigators carried out an in-vitro evaluation of the repair of mainly single-stranded DNA breaks after peripheral blood radiation of 48 children with systemic lupus erythematosus, systemic sclerosis, juvenile rheumatoid arthritis, and dermatomyositis. Greater DNA damage and a delay in DNA repair were noted in the children with connective tissue diseases group than in healthy children. ${ }^{43}$ Another in-vitro study that used tritiated thymidine incorporation assays showed that patients with active systemic lupus erythematosus had increased radiotherapy-related lymphocytic sensitivity when compared with healthy patients when irradiated with ${ }^{60} \mathrm{Co}-\gamma$ photons between $0 \mathrm{~Gy}$ and $10 \mathrm{~Gy}$, resulting in a potentially higher probability of radiation toxicity. ${ }^{42}$

Similarly, immune system changes, which can affect radiosensitivity, are being investigated. Among others, Budach and colleagues ${ }^{44}$ investigated the possibly abnormal reaction to high radiation doses in two groups of germline mutation-carrying mice, one with severe combined immunodeficiency (SCID; even though it is not classified as a connective tissue disease) and one that had normal radiation sensitivity $(\mathrm{C} 3 \mathrm{H})$. The lethal dose for $50 \%$ of the irradiated animals after single-dose whole-body irradiation was lower for SCID mice than for $\mathrm{C} 3 \mathrm{H}$ mice, as was the radiation dose that was needed to achieve $50 \%$ local control and tumour growth delay, 
thus confirming that abnormal radiation sensitivity was observed in SCID mice. ${ }^{44} \mathrm{~A}$ possible mechanism correlated with increased sensitivity of SCID tumour cell lines is the inability of the tumour cells to overcome their genetic deficiency in DNA double-strand break repair in SCID fibroblasts. ${ }^{45}$

More than 300 cases involving patients with connective tissue diseases have been published reporting toxicity after radiotherapy and several early and late radiotherapyrelated complications, including some deaths, have also been reported. ${ }^{2,5,7,10,46}$ The first two severe events in patients with connective tissue diseases given radiotherapy were noted in the late $1960 \mathrm{~s} .{ }^{47,48}$ In one case, a patient with systemic lupus erythematosus who had lymphoma died of heart failure 1 year after radiotherapy to the mediastinal and retroclavicular nodes (20 Rad [20 Gy] and $39 \mathrm{Rad}$ [39 Gy], respectively, with ${ }^{60 \mathrm{Co}}$ ), ${ }^{47}$ whereas the second patient, who had facial lupus, developed radiotherapy-correlated osteomyelitis of the maxilla. ${ }^{48}$ However, no data about radiotherapy dose or modality were provided. Teo and colleagues ${ }^{1}$ assessed the radiation toxicity profiles of ten patients with a diagnosis of early-stage nasopharyngeal carcinoma and dermatomyositis (table 1). At a median follow-up of 51.8 months, all patients had subcutaneous fibrosis and xerostomia, two patients had radiation skin necrosis, and one patient had a VI and XII cranial nerve deficit. ${ }^{1}$ However, no information was provided about radiotherapy dose and techniques.

Fleck and colleagues ${ }^{2}$ published a study of nine patients with breast cancer (four women with a pre-existing connective tissue disease and five who developed a connective tissue disease after radiotherapy). Eight received radiotherapy using ${ }^{60} \mathrm{Co}$ with a prescription dose of 40-50 Gy and an electron boost on the tumour bed of 5-15 Gy. Three patients with a pre-existing connective tissue disease reported a severe toxicity profile: the first case involved moist desquamation and brachial plexopathy; the second case showed soft-tissue necrosis needing chest-wall resection, rib fractures, and pulmonary fibrosis; and the third patient had soft-tissue necrosis, bronchopleural-cutaneous fistula, and osteonecrosis of the clavicle, sternum, and rib. None of the patients with a new diagnosis of connective tissue diseases after radiotherapy had severe complications. ${ }^{2}$

According to McCormick, ${ }^{49}$ to reduce the side-effects in patients with connective tissue disease and breast cancer, a more aggressive local surgery and systemic therapy, in particular for younger women ( $<40$ years), was better than breast-conserving surgery followed by radiation. More recently, accelerated partial breast irradiation by either brachytherapy or intraoperative radiotherapy has been considered an alternative experimental option for the treatment of early-stage breast cancer in women with a history of connective tissue diseases. Dragun and colleagues $^{9}$ published a report of nine patients with connective tissue diseases with breast cancer given accelerated partial breast irradiation via high-dose brachytherapy; toxicity and cosmetic profiles were reported as satisfactory. Indeed, the authors concluded that it might not be necessary to exclude patients with connective tissue diseases from clinical trials of accelerated partial breast irradiation. As confirmation, Turesson and colleagues ${ }^{6}$ reported that autoimmune disease did not increase the risk of skin teleangectasia in 35 patients who received radiotherapy for breast cancer. Finally, Lowell and colleagues ${ }^{10}$ published data on the use of a very high dose of radiation delivered with gamma knife for brain metastases in 14 patients with connective tissue diseases, and reported no grade 3 or 4 toxicity (table 1 ).

In conclusion, in-vitro studies and clinical case reports describe a narrow and heterogeneous picture for patients with connective tissue diseases who receive radiotherapy. Despite these data limitations, more recently published data show that patients with connective tissue diseases seem to be less affected by toxicity than are healthy individuals and case reports (table 1).

\section{Retrospective and controlled studies}

To our knowledge, no randomised controlled study has assessed whether patients with connective tissue diseases are more likely to develop acute or late radiotherapyrelated toxicity. However, we retrieved 11 case series. ${ }^{11-21}$ In a retrospective analysis, Morris and Powell ${ }^{12}$ reported a large series of 209 patients with connective tissue diseases given radiotherapy with a median radiation dose of $45 \mathrm{~Gy}$ (range 13-82) between 1960 and 1995. After a median follow-up of 6 years, clinically significant acute side-effects (Radiation Therapy Oncology Group/Eastern Cooperative Oncology Group RTOG/ECOG Early Morbidity Scoring Scale of more than three) were similar in patients with and without rheumatoid arthritis (both 12\%). At 5 years, the risk of late morbidity for patients with rheumatoid arthritis was $6 \%$, similar to the rate for the healthy population generally, whereas for patients without rheumatoid arthritis it was $21 \%(\mathrm{p}=0.0002)$. The most highly represented connective tissue disease after rheumatoid arthritis was systemic lupus erythematosus, with 25 patients (12\%). No correlation between dose, fraction size, irradiated volume, and late effects were reported. ${ }^{12}$

Similar results were reported in a matched-control study of 61 patients with connective tissue diseases. ${ }^{11}$ The number of acute reactions after radiotherapy in the connective tissue diseases group was only slightly higher than in the matched-control group, with grade 3 or greater acute toxicity noted in seven patients in the connective tissue diseases group and four in the matched-control group. Patients with systemic lupus erythematosus had an increase in the number of acute reactions due to radiation (36\% of patients with systemic lupus erythematosus vs $18 \%$ in the control group, $\mathrm{p}=0 \cdot 5$ ), whereas patients with rheumatoid arthritis had 
an increase in late complications (24\% vs 5\%; $\mathrm{p}=0 \cdot 125)$. Nevertheless, the study showed no significant differences in acute and late toxicity complications between groups. ${ }^{11}$

Chen and colleagues ${ }^{13}$ reported no significant differences in acute complications after breast cancer radiotherapy between a group of 36 women with connective tissue diseases and a matched-control group (14\% vs $8 \%$, respectively; $\mathrm{p}=0 \cdot 40$ ), but did note a significant difference in late toxicity in those patients with connective tissue diseases (17\% vs 3\%; $\mathrm{p}=0 \cdot 0095)$. However, when the investigators stratified patients by specific autoimmune disease, they found a significant difference only in four patients with scleroderma. ${ }^{13}$ Phan and colleagues ${ }^{14}$ assessed 76 patients who received radiation for cancer (38 patients with connective tissue diseases and 38 in the control group) and did not show any significant differences in terms of acute or late complications between groups. However, increased risk of radiation complications was reported in patients with scleroderma $(n=4)$.

In another study, Lin and colleagues ${ }^{18}$ reported toxic effects in 73 patients with connective tissue diseases given radiotherapy. No differences were noted in acute toxicity between patients with connective tissue diseases and those in the control group. However, patients with a diagnosis of connective tissue diseases had a significantly higher incidence of late toxicity compared with the control group ( $29 \%$ vs $14 \%$, respectively; $\mathrm{p}=0 \cdot 001$ ), with a non-significant increase in severe late toxicity ( $9 \%$ vs $4 \%$; $\mathrm{p}=0 \cdot 079$ ). Patients with diagnosed connective tissue diseases who received radiation to the pelvis had a higher probability of severe toxicity reactions (grade 3 or higher); furthermore, the incidence of severe late toxicity was higher in patients with a diagnosis of systemic lupus erythematosus and scleroderma than in the control group. ${ }^{18}$

Gold and colleagues ${ }^{19}$ retrospectively analysed the toxicity profile of 41 patients with connective tissue diseases given radiation for cancer (20 patients with systemic sclerosis and 21 patients with systemic lupus erythematosus). Patients were divided into high-severity and low-severity connective tissue diseases on the basis of the number of involved organs. Univariate analysis showed a significant increase in the risk of any grade toxicity for patients with high-severity connective tissue diseases compared with those with low-severity connective tissue diseases $(\mathrm{p}=0.006)$, although no differences in grade 3 or higher toxicity were found between the two groups $(\mathrm{p}=0 \cdot 56)$. Despite the small number of enrolled patients, the severity of connective tissue diseases could be considered as an important factor in the prediction of treatment tolerability. Nonetheless, the severity of connective tissue diseases was not a clear contraindication to radiotherapy. ${ }^{19}$

Varga and colleagues ${ }^{3}$ reported on the toxicity profile of four patients with systemic sclerosis who were given radiotherapy. ${ }^{3}$ All patients had cutaneous and subcutaneous late toxicity, visceral fibrotic reactions at the radiation site, and severe skin toxicity and fibrosis extending beyond the radiation field involving internal organs. Three of the four patients subsequently died, two from bowel obstruction and one from pneumonia. ${ }^{3}$

Liu and colleagues ${ }^{15}$ planned a prospective study to investigate the effect of neoadjuvant androgen-deprivation therapy and radiotherapy in men with prostate cancer. A subanalysis showed that 15 of the men had a connective tissue disease and that these patients had a greater frequency of late genitourinary grade 2 toxicities compared with healthy men (relative risk $3 \cdot 98 ; \mathrm{p}=0 \cdot 007$ ). ${ }^{15}$

As previously stated, several studies have reported radiotherapy-related toxicity profiles in patients with a range of connective tissue diseases (tables 1, 2). Nevertheless, only a few of the studies ${ }^{7,8,17,20}$ focused on patients with scleroderma and systemic lupus erythematosus, with contentious conclusions about radiotherapy toxicity.

Gold and colleagues ${ }^{17}$ assessed the toxicity profiles of 20 patients with scleroderma and cancer who had been treated with radiotherapy or brachytherapy or both, with or without concurrent chemotherapy. Univariate analysis showed a significant association between acute toxicity, radiotherapy dose, and increased scleroderma involvement of organs. For late side-effects, negative antinuclear antibody serology was correlated with a higher probability of toxicity. None of the analysed pretreatment and treatment variables were correlated with severe acute and late toxicity. ${ }^{17}$ There have been no further reports to confirm severe acute and late complication profiles in this specific setting. ${ }^{7,8,10}$

Rakfal and Deutsch ${ }^{7}$ described data for six patients who had a diagnosis of systemic lupus erythematosus and different malignancies with various radiotherapy doses, reporting no unexpected severe acute or late side-effects. Khoo and colleagues ${ }^{8}$ reported no relevant acute or late complications in two patients with anal cancer with systemic lupus erythematosus taking concomitant immunosuppressive therapy who were treated with combined chemoradiotherapy $\left({ }^{60} \mathrm{Co}\right.$ and external-beam radiotherapy).

One of the most important reports was published by Pinn and colleagues, ${ }^{20}$ which included 21 patients with systemic lupus erythematosus who received a total of 35 consecutive courses of radiotherapy. Of the 17 patients who were evaluable for late toxicity, four patients (24\%) had a grade 3 or higher toxicity. The presence of renal involvement according to the American Rheumatism Association criteria was correlated with an increased risk of any grade of late toxicity $(\mathrm{p}<0.006)$. Univariate analysis established a correlation between acute toxicity and total dose $(>49.8 \mathrm{~Gy})$, treatment sites, and curative intent for treatment. Brachytherapy was used in one treatment course, 2D radiotherapy in 30 courses, 3D conformal radiotherapy in three, and intensitymodulated radiotherapy in one. Moreover, absence of photosensitivity $(\mathrm{p}<0.02)$, absence of arthritis $(\mathrm{p}<0.03)$, and presence of a malar rash $(\mathrm{p}<0.04)$ were correlated 
with an increased risk of grade 3 or greater acute toxicity. No specific association between technique and late toxicity was noted. Radiation dose prescription, radiation techniques, and anatomical site (ie, abdomen, pelvis, breast, brain, neck, and chest) were associated with a high risk of any late toxicity.

In conclusion, the small number of described cases and the heterogeneity of the connective tissue disease seem to strongly affect the statistical power of these studies, thus limiting the possibility to show any robust association between radiation toxicity and connective tissue diseases, and confirming that radiotherapy is frequently withheld unjustly to treat patients with connective tissue diseases..$^{16,19,21}$

\section{Clinical solutions and future perspectives}

Various treatment strategies have been considered for patients with connective tissue diseases to reduce the risk of toxicity during or after radiotherapy such as avoiding concomitant treatment or reducing dose prescription. Although the use of chemoradiotherapy is considered the gold standard in many cases, multimodality treatment in patients with connective tissue diseases could be correlated with a more severe toxicity profile than single-modality treatment, thereby affecting its feasibility. ${ }^{4,12,19,50}$ In radiotherapy, the radiation dose could be reduced to lower the toxicity profile, but this could impair effectiveness. ${ }^{12,28,44,51}$ However, Delanian and colleagues ${ }^{52}$ reported that reducing radiation dose (from $65 \mathrm{~Gy}$ to $40 \mathrm{~Gy}$ ) in patients with connective tissue diseases (one with lung cancer and two with anal-rectal cancer) resulted in complete remission, although side-effects were observed at the radiation site. Some investigators have postulated that hyperactivation of the immune system by tumour cells makes patients with connective tissue diseases more sensitive to radiation than others. ${ }^{53,54}$ Another strategy is changing dose fractionation schedules or reducing treatment volume, which might decrease toxicity complications. ${ }^{2,12,28,40,51,52,54}$ Nevertheless, a crucial question still remains-is it really necessary to modify radiotherapy features to decrease toxicity in patients with connective tissue diseases?

The most common radiotherapy approach is to use external beams to deliver ionising radiation. In the past few decades, most departments have replaced their ${ }^{60} \mathrm{Co}$ machines with the more precise linear accelerator. Despite modern radiotherapy now being available, most reports of patients with connective tissue diseases involve obsolete and unsatisfactory technologies including 2D radiotherapy. Intensity-modulated radiotherapy and stereotactic ablative radiotherapy have allowed radiation oncologists to prescribe higher dose prescriptions to targets when useful or required. Intensity-modulated radiotherapy is considered an advancement of 3D-conformal radiotherapy that targets the radiation dose into the tumour, thus minimising the exposure of healthy tissue in several anatomical regions. Intensity-modulated

\section{Search strategy and selection criteria}

We searched Medline, Google Scholar, PubMed, and the ProQuest Dissertation, and Theses databases for reports published in English from June, 1946, to Jan 1, 2015. Our detailed search algorithm is shown in the appendix. We identified additional references with a manual review of the reference lists of included articles.

Two independent reviewers (NGL and SS) identified potential studies and exported them to an electronic reference management software program (RefWorks version 2.0). NGL and SS determined eligibility by reviewing first the title and abstract and then the full paper. Disagreements were resolved by consensus; if consensus was not achieved, then a third author (FA) provided an assessment of eligibility. Because the data for eligibility were dichotomous (yes vs no), we established inter-rater agreement at both the title and abstract review and the full article review stages by calculating Cohen's $\mathrm{k}$ coefficient. A study was included when it reported on cancer-related radiotherapy and included patients with connective tissue diseases. A study was excluded when no detailed information (eg, outcome of radiotherapy, clinical manifestations related to the underlying connective tissue diseases, solid evidence of diagnosis of connective tissue diseases) was reported. Review articles were excluded from the analysis. For data extraction, all the papers were scrutinised for the following information: study design (retrospective, prospective, case-control, cross-sectional and case series, or case report); number of patients, sex, and age (mean, range); type of radiotherapy; type of underlying connective tissue disease; type of underlying cancer; definition of radiotherapy acute and late toxicity profile; outcome in terms of toxicity profile; and timing of connective tissue diseases onset or exacerbation.

radiotherapy is considered the most appropriate technique in head and neck cancers and in most pelvic tumours, including prostate cancer. In this disease, intensity-modulated radiotherapy decreased long-term toxicity with no negative effect on overall survival when compared with 3D-conformal radiotherapy..$^{54-66}$

Stereotactic ablative radiotherapy is a novel radiotherapy method that delivers a very high dose of radiation (in a single or a few fractions) with high precision to the tumour, thus maximising the sparing of surrounding normal tissue. Several retrospective and prospective stereotactic ablative radiotherapy studies have shown promising results in terms of local tumour control and survival in some settings, including in early non-small-cell lung cancer. ${ }^{67}$ Moreover, image-guided radiotherapy based on daily patient set-up position verification allowed better definition of the tumour target to reduce and ultimately eliminate uncertainties. To our knowledge, no randomised controlled trials using image-guided radiotherapy have assessed toxicity and efficacy in patients with connective tissue disease. Hence, the promising, modern techniques could improve radiotherapy tolerability, especially in challenging clinical situations, as well as in patients with connective tissue diseases and cancer. ${ }^{68,69}$

\section{Conclusion}

The data that are currently available from case series and a few retrospective studies are still not enough to support a specific contraindication for radiotherapy in patients with connective tissue diseases. Nevertheless, a cautious approach for patients with active connective
See Online for appendix For more on Cohen's K coefficient see http://facultyvassaredu/lowry/ kappa.html 
tissue diseases seems to be reasonable. Moreover, the recent implementation of new radiotherapy approaches could be promising to improve the feasibility and tolerability of radiotherapy in some patients with cancer, including those with connective tissue diseases. Further well designed prospective studies, which also assess the most appropriate total dose and fractionation schedules, will probably help to overcome the unresolved concerns about radiotherapy indication for patients with connective tissue diseases.

\section{Contributors}

FA, NGL, and SS searched the literature, assisted with the organisation of the manuscript, interpreted and collected data, and wrote and edited the Review. AF and DR assisted with the organisation of the manuscript, interpreted and collected data, and wrote and edited the Review. SF, RM, and FR interpreted and collected data, helped to design the figures and panel, and wrote and edited the Review.

\section{Declaration of interests}

We declare no competing interests.

References

1 Teo P, Tai TH, Choy D. Nasopharyngeal carcinoma with dermatomyositis. Int J Radiat Oncol Biol Phys 1989; 16: 471-74.

2 Fleck R, McNeese MD, Ellerbrook MA, et al. Consequences of breast irradiation in patients with pre-existing collagen vascula diseases. Int J Radiat Oncol Biol Phys 1989; 17: 829-33.

3 Varga J, Haustein UF, Creech RH, et al. Exaggerated radiation-induced fibrosis in patients with systemic sclerosis. JAMA 1991; 265: 3292-95.

4 Hareyama M, Nagakura H, Tamakawa M, et al. Severe reaction after chemoradiotherapy of nasopharyngeal carcinoma with collagen disease. Int J Radiat Oncol Biol Phys 1995; 33: 971.

5 Bliss P, Parsons CA, Blake PR. Incidence and possible aetiological factors in the development of pelvic insufficiency fractures following radical radiotherapy. $\mathrm{Br} J$ Radiol 1996; 69: 548-54.

6 Turesson I, Nyman J, Holmberg E, Odén A. Prognostic factors for acute and late skin reactions in radiotherapy patients. Int J Radiat Oncol Biol Phys 1996; 36: 1065-75.

7 Rakfal SM, Deutsch M. Radiotherapy for malignancies associated with lupus: case reports of acute and late reactions. Am J Clin Oncol 1998; 21: 54-57.

8 Khoo VS, Saunders MP, Gowda R, et al. Anal canal cancer and chemoradiation treatment in two patients with systemic lupus erythematosus treated by chronic therapeutic immunosuppression. Clin Oncol (R Coll Radiol) 2004; 16: 1-5.

9 Dragun AE, Harper JL, Olyejar SE, et al. The use of adjuvant high-dose-rate breast brachytherapy in patients with collagen vascular disease: a collaborative experience. Brachytherapy 2011; 10: $121-27$.

10 Lowell D, Tatter SB, Bourland JD, et al. Toxicity of gamma knife radiosurgery in the treatment of intracranial tumors in patients with collagen vascular diseases or multiple sclerosis. Int J Radiat Oncol Biol Phys 2011; 81: e519-24.

11 Ross JG, Hussey DH, Mayr NA, Davis CS. Acute and late reactions to radiation therapy in patients with collagen vascular diseases. Cancer 1993; 71: 3744-52.

12 Morris MM, Powell SN. Irradiation in the setting of collagen vascular disease: acute and late complications. J Clin Oncol 1997; 15: 2728-35.

13 Chen AM, Obedian E, Haffty BG. Breast-conserving therapy in the setting of collagen vascular disease. Cancer J 2001; 7: 480-91.

14 Phan C, Mindrum M, Silverman C, Paris K, Spanos W. Matched-control retrospective study of the acute and late complications in patients with collagen vascular diseases treated with radiation therapy. Cancer J 2003; 9: 461-66.

15 Liu M, Pickles T, Agranovich A, et al. Impact of neoadjuvant androgen ablation and other factors on late toxicity after external beam prostate radiotherapy. Int J Radiat Oncol Biol Phys 2004; 58: 59-67.

16 Benk V, Al-Herz A, Gladman D, et al. Role of radiation therapy in patients with a diagnosis of both systemic lupus erythematosus and cancer. Arthritis Rheum 2005: 53: 67-72.
17 Gold DG, Miller RC, Petersen IA, Osborn TG. Radiotherapy for malignancy in patients with scleroderma: The Mayo Clinic experience. Int J Radiat Oncol Biol Phys 2007; 67: 559-67.

18 Lin A, Abu-Isa E, Griffith K, Ben-Josef E. Toxicity of radiotherapy in patients with a collagen vascular disease. Cancer 2008; 113: 648-53.

19 Gold DG, Miller RC, Pinn ME, et al. Chronic toxicity risk after radiotherapy for patients with systemic sclerosis (systemic scleroderma) or systemic lupus erythematosus: association with connective tissue disorder severity. Radiother Oncol 2008; 87: 127-31.

20 Pinn ME, Douglas G, Gold G, et al. Systemic lupus erythematosus, radiotherapy, and the risk of acute and chronic toxicity: the mayo clinic experience. Int J Radiat Oncol Biol Phys 2008; 71: 498-506.

21 Patel AB, Hallemeier CL, Petersen IA, et al. Acute and late toxicities of radiotherapy for patients with discoid lupus erythematosus: a retrospective case-control study. Radiat Oncol 2012; 7: 22.

22 Winchester DP, Cox JD. Standards for diagnosis and management of invasive breast carcinoma. American College of Radiology. American College of Surgeons. College of American Pathologists. Society of Surgical Oncology. CA Cancer J Clin 1998; 48: 83-107.

23 Pons-Estel GJ, Alarcón GS, Scofield L, et al. Understanding the epidemiology and progression of systemic lupus erythematosus. Semin Arthritis Rheum 2010; 39: 257-68.

24 Goldblatt F, O'Neill SG. Clinical aspects of autoimmune rheumatic diseases. Lancet 2013; 382: 797-808.

25 Schreiber RD, Old LJ, Smyth MJ. Cancer immunoediting: integrating immunity's roles in cancer suppression and promotion. Science 2011; 331: 1565-70.

26 Joseph CG, Darrah E, Shah AA, et al. Association of the autoimmune disease scleroderma with an immunologic response to cancer. Science 2014; 343: 152-57.

27 Shah AA, Rosen A, Hummers L, et al. Close temporal relationship between onset of cancer and scleroderma in patients with RNA polymerase I/III antibodies. Arthritis Rheum 2010; 62: 2787-95.

28 Chon BH, Loeffler JS. The effect of non malignant systemic disease on tolerance to radiation therapy. Oncologist 2002; 7: 136-43.

29 Lee CE, Prabhu V, Slevin NJ. Collagen vascular diseases and enhanced radiotherapy-induced normal tissue effects-a case repor and a review of published studies. Clin Oncol ( $R$ Coll Radiol) 2011; 23: 73-8.

30 Kim R, Emi M, Tanabe K. Cancer immunoediting from immune surveillance to immune escape. Immunology 2007; 121: 1-14.

31 Jain RK. Transport of molecules, particles, and cells in solid tumors Annu Rev Biomed Eng 1999; 1: 241-63.

32 Matzinger P. Tolerance, danger, and the extended family. Annu Rev Immunol 1994; 12: 991-1045.

33 Shankaran V, Ikeda H, Bruce AT, et al. IFNgamma and lymphocytes prevent primary tumour development and shape tumour immunogenicity. Nature 2001; 410: 1107-11.

34 Demaria S, Formenti SC. Sensors of ionizing radiation effects on the immunological microenvironment of cancer. Int J Radiat Oncol Biol Phys 2007; 83: 819-25.

35 Zou W. Immunosuppressive networks in the tumour environment and their therapeutic relevance. Nat Rev Cancer 2005; 5: 263-74.

36 Lippitz BE. Cytokine patterns in patients with cancer: a systematic review. Lancet Oncol 2013; 14: e218-28.

37 Westbury CB, Yarnold JR. Radiation fibrosis-current clinical and therapeutic perspectives. Clinical Oncology 2012; 24: 657-72

38 Wang J, Boerma M, Fu Q, Hauer-Jensen M. Significance of endothelial dysfunction in the pathogenesis of early and delayed radiation enteropathy. World J Gastroenterol 2007; 13: 3047-55.

39 Rabbani ZN, Mi J, Zhang Y, et al. Hypoxia inducible factor 1alpha signaling in fractionated radiation-induced lung injury: role of oxidative stress and tissue hypoxia. Radiat Res 2010; 173: 165-74.

40 Brush J, Lipnick SL, Phillips T, et al. Molecular mechanisms of late normal tissue injury. Semin Radiat Oncol (US) 2007; 17: 121-30.

41 Carrillo-Alascio, McCurdy D, Tai LQ, et al. In-vitro radiosensitivity in patients with systemic lupus erythematosus. Lupus 2009; 18: 645-49.

42 Cossu F, Rombi G, Aresu G, et al. Radiosensitivity of lymphocyte subpopulations in subjects with systemic lupus erythematosus. A in vitro preliminary study. Minerva Med 1991; 82: 239-49. 
43 McCurdy D, Tai LQ, Frias S, Wang Z. Delayed repair of DNA damage by ionizing radiation in cells from patients with juvenile systemic lupus erythematosus and rheumatoid arthritis. Radiat Res 1997; 147: 48-54.

44 Budach W, Hartford A, Gioioso D et al. Tumors arising in SCID mice share enhanced radiation sensitivity of SCID normal tissues. Cancer Res 1992; 52: 6292-96.

45 Biedermann, KA, Sun, JR, Giaccia AJ, et al. SCID mutation in mice confers hypersensitivity to ionizing radiation and a deficiency in DNA double-strand break repair. Proc Natl Acad Sci USA 1991; 88: 1394-97.

46 Olivotto IA, Fairey RN, Gillies JH, Stein H. Fatal outcome of pelvic radiotherapy for carcinoma of the cervix in a patient with systemic lupus erythematosis. Clin Radiol 1989; 40: 83-84.

47 Nilsen LB, Missal ME, Condemi JJ. Appearance of Hodgkin's disease in a patient with systemic lupus erythematosus. Cancer 1967; 20: 1930-33.

48 Glasenapp GB. Osteomyelitis of the maxilla following radiotherapy for facial lupus. HNO 1968; 16: 46-49.

49 McCormick B. Selection criteria for breast conservation. The impact of young and old age and collagen vascular disease. Cancer 1994; 74: 430-35.

50 De Naeyer B, De Meerleer G, Braems S, et al. Collagen vascular diseases and radiation therapy: a critical review. Int J Radiat Oncol Biol Phys 1999; 44: 975-80.

51 Abu-Shakra M, Lee P. Exaggerated fibrosis in patients with systemic sclerosis (scleroderma) following radiation therapy. J Rheumatol 1993; 20: 1601-03.

52 Delanian S, Maulard-Durdux C, Lefaix JL, et al. Major interactions between radiation therapy and systemic sclerosis: is there an optimal treatment? Eur J Cancer 1996; 32A: 738-39.

53 Gery B, Roussel A, Valla A. Usefulness of radiotherapy in the treatment of advanced gastrinomas. Radiother Oncol 1993; 27: 259-60.

54 Cooper SG, Denham JW. Progressive systemic sclerosis (diffuse scleroderma) and radiotherapy. Br J Radiol 1990; 63: 804-05.

55 Chi A, Nguyen NP, Tse W, et al. Intensity modulated radiotherapy for sinonasal malignancies with a focus on optic pathway preservation. J Hematol Oncol 2013; 6: 4.

56 Eisbruch A. Reducing xerostomia by IMRT: what may, and may not, be achieved. J Clin Oncol 2007; 25: 4863-64.

57 Madani I, Bonte K, Vakaet L, et al. Intensity-modulated radiotherapy for sinonasal tumors: Ghent University Hospital update. Int J Radiat Oncol Biol Phys 2009; 73: 424-32.
58 Wolden SL, Chen WC, Pfister DG, et al. Intensity-modulated radiation therapy (IMRT) for nasopharynx cancer: update of the Memorial Sloan-Kettering experience. Int J Radiat Oncol Biol Phys 2006; 64: 57-62.

59 Garden AS, Morrison WH, Wong P-F, et al. Disease-control rates following intensity-modulated radiation therapy for small primary oropharyngeal carcinoma. Int J Radiat Oncol Biol Phys 2007; 67: 438-44.

60 Lee NY, de Arruda FF, Puri DR, et al. A comparison of intensity-modulated radiation therapy and concomitant boost radiotherapy in the setting of concurrent chemotherapy for locally advanced oropharyngeal carcinoma. Int J Radiat Oncol Biol Phys 2006; 66: 966-74.

61 deArruda FF, Puri DR, Zhung J, et al. Intensity-modulated radiation therapy for the treatment of oropharyngeal carcinoma the Memorial Sloan-Kettering Cancer Center experience. Int J Radiat Oncol Biol Phys 2006; 64: 363-73.

62 Jacobs BL, Zhang Y, Schroeck FR, et al. Use of advanced treatment technologies among men at low risk of dying from prostate cancer. JAMA 2013; 309: 2587-89.

63 Jani AB, Gratzle J, Correa D. Influence of intensity-modulated radiotherapy on acute genitourinary and gastrointestinal toxicity in the treatment of localized prostate cancer. Technol Cancer Res Treat 2007; 6: 11-15.

64 Goldin GH, Sheets NC, Meyer AM, et al. Comparative effectivenes of intensity-modulated radiotherapy and conventional conformal radiotherapy in the treatment of prostate cancer after radical prostatectomy. JAMA Intern Med 2013; 173: 1136-43.

65 Pollack A, Walker G, Horwitz EM, et al. Randomized trial of hypofractionated external-beam radiotherapy for prostate cancer. J Clin Oncol 2013; 31: 3860-68.

66 Arcangeli S, Strigari L, Gomellini S, et al. Updated results and patterns of failure in a randomized hypofractionation trial for high-risk prostate cancer. Int J Radiat Oncol Biol Phys 2012; 84: $1172-78$.

67 Alongi F, Arcangeli S, Filippi AR, et al. Review and uses of stereotactic body radiation therapy for oligometastases. Oncologist 2012; 17: 1100-07.

68 Allison RR, Gay HA, Mota HC, et al. Image-guided radiation therapy: current and future directions. Future Oncol 2006; 2: 477-92.

69 Perkins CL, Fox T, Elder E, et al. Image-guided radiation therapy (IGRT) in gastrointestinal tumors. JOP 2006; 7: 372-81. 